\title{
Improving Cotton Yield, Water Use and Net Income in Different Drip Irrigation Systems Using Real-Time Crop Evapotranspiration
}

\author{
Öner Çetin ${ }^{1 *}$, Neşe Üzen¹, Mefhar Gültekin Temiz², Hilal Altunten¹ \\ ${ }^{1}$ Dicle University, Faculty of Agriculture, Department of Agricultural Structures and Irrigation, Diyarbakir, Turkey \\ ${ }^{2}$ Dicle University, Faculty of Agriculture, Department of Field Crops, Diyarbakir, Turkey
}

Received: 24 November 2020

Accepted: 11 February 2021

\begin{abstract}
The purpose of this study was to improve irrigation water use and cotton yield using real-time crop evepotranspiration based on the FAO-56 Penman-Monteith and canopy cover using surface drip and subsurface drip irrigation. The experiments were conducted Southeast Anatolia Region of Turkey, during 2016 and 2017. The experimental design was split-plots in randomized blocks using three replications. The main plots were surface drip irrigation (SDI), subsurface drip irrigation (SSDI-30 cm) and SSDI-40 cm. Sub-plots were three different irrigation levels based on real crop evapotranspiration $(\mathrm{ETc}), 0.75 \times \mathrm{ETc}, 1.00 \times \mathrm{ETc}$ and $1.25 \times \mathrm{ETc}$. There were significant differences $\left(657 \mathrm{~kg} \mathrm{ha}^{-1}\right)$ between the seed cotton yield of SDI (3667 kg ha-1) and SSDI with a 40-cm lateral depth (4323 kg ha-1). Irrigation water and crop consumptive water use were 552 and $589 \mathrm{~mm}$ for the SSDI-40 $\mathrm{cm}$ recommended treatment, respectively. According to the projection using the results for cotton cultivation area in the study region, SDI and SSDI could save water about 37 and $42 \%$ compared to furrow irrigation, respectively. Net income based on unit area in SDI and SSDI was higher 20 and 69\% than it in furrow irrigation, respectively. Irrigation scheduling based on real crop evapotranspiration $(1.0 \times \mathrm{ETc})$ was more appropriate for water saving and increasing water productivity $\left(0.84 \mathrm{~kg} \mathrm{~m}^{-3}\right)$. The use of drip irrigation systems (especially SSDI) is significantly important to improve cotton yield, water use and economic contribution considering possible water shortage, decreasing water resources, farmers conditions, irrigation schemes, regional and national incomes.
\end{abstract}

Keywords: canopy cover, cotton, FAO-56 Penman-Monteith, subsurface drip, surface drip

*e-mail: oner_cetin@yahoo.com 


\section{Introduction}

Agriculture is most water-demanding, compared to other sectors [1]. However, irrigation efficiency, in general, is far less than desired due to the use of inappropriate methods, mismanagement, and farmer customs for surface irrigation in the study region. Surface irrigation methods are still most widely used for irrigating cotton in Turkey [2].

In the previous study, cotton has been shown requiring $\geq 1000 \mathrm{~mm}\left(10000 \mathrm{~m}^{3} \mathrm{ha}^{-1}\right)$ water with surface irrigation methods in the study area [3]. In addition, the study region has been producing about $50 \%$ of the total seed cotton production in Turkey [4]. Thus, cotton is the main and most important crop and consumes a large amount of water with surface irrigation. Irrigation water productivity is low for surface irrigation in the study area for the cotton. Hence, the use of surface drip irrigation (SDI) [3, 5, 6] and/or subsurface drip irrigation (SSDI) plays a key role in saving water and increasing water productivity [7-9].

The use of drip irrigation systems in the world has immensely increased due to the developing plastic industry. The advantages of the drip irrigation systems, in general, include higher water and nutrient use efficiency, increased crop yield and quality, and water saving $[5,6,10,11]$. Thus, drip irrigation systems have been widely used in arid and semi-arid regions in recent years in terms of both irrigation water and labor savings [12].

A decreased amount of irrigation water using drip irrigation could be possible because the whole surface area of the field is not irrigated [13]. This event specifically develops at the beginning of the growing season, which is when the canopy cover is not completely developed and evaporation from the soil surface could be decreased. Thus, drip irrigation methods save considerable water compared to surface irrigations. One of the most favorable ways of decreasing evaporation from the soil surface is to use SSDI [8, 14, 15].

Çetin \& Bilgel [3] have shown that seed cotton yield increased by $21 \%$ for SDI compared to furrow irrigation and that SDI also saved 33\% more amount of irrigation water compared to surface irrigation (furrow) in the study region. Thus, the significant amount of irrigation water, about $33 \%$ of $1000 \mathrm{~mm}$, could be conserved each year by implementing proper irrigation techniques and scheduling for cotton irrigation. In addition, there have been several studies regarding the effect of SDI on cotton in Turkey, and the researchers have shown an increase in seed cotton yield and water saving using SDI [3, 5, 16]. Some researchers have shown that the use of SSDI for cotton has increased dramatically, especially in areas with water shortages [7, 17-19].

The highest seed cotton yield using SSDI in the different region of Turkey was obtained with a multiple of 0.90 of evaporation from the Class A Pan. However, the use of a lateral depth of $30 \mathrm{~cm}$ for SSDI has posed soil plough problems [20]. Although considerable studies have been carried out on surface drip and/or subsurface drip irrigation regarding irrigation water saving and increasing yield in recent years [5, 6, 15, 21 22], there have been no appropriate studies on the use of SSDI based on real-time water consumption by crop on cotton in the study region.

On the other hand, there were no major differences in crop evapotranspiration among the irrigation methods/systems. However, the wetted soil surface and the frequent or higher intervals of irrigation affect the evaporation; thus, these circumstances could be decreasing or increasing the effects of evapotranspiration [14]. Kamilov et al. [23] compared the use of furrow irrigation and SSDI on the cotton yield, and SSDI provided an added yield of $21 \%$.

The accurate estimation of ETc is crucial for irrigation scheduling and efficient water management. Thus, different methods and measurements has been used to estimate ETc and water-saving potential and to develop irrigation scheduling for optimal crop production [22]. New approaches and strategies on efficient water use without decreasing yield should be forward.

There were, thus, many earlier studies on irrigation scheduling studies based on soil moisture deficit, class A pan and/or critical stages of the crop for cotton. The main purpose of this study is to improve water use efficiency and to save more irrigation water in cotton irrigation using real-time crop evapotranspiration based on the FAO-56 Penman-Monteith (FAO-56 PM).

\section{Material and Methods}

\section{Study Area}

Field trials were conducted in the Experimental Station of Dicle University, Agricultural Faculty in Diyarbakır, Turkey, during the 2016 and 2017 growing season. The study area is located at the Research Station of Faculty of Agriculture in Dicle University, Diyarbakır, Turkey (3754'11'N; 40¹3'48'E). The soils of the experimental site had flat sloppy and $\mathrm{ABC}$ profiles with a heavy texture (Clay content is about $65 \%$ ). The soil texture, $\mathrm{pH}$, organic matter and electrical conductivity (EC) were clay, 7.7, 1.7\% and $0.48 \mathrm{dS} \mathrm{m}^{-1}$, respectively. The soils contained higher lime (11\%) and potassium (561 ppm K); however, had lower organic matter and phosphorus ( 8 ppm P). There was no salinity or alkalinity, and there were no drainage problems.

The climate is continental and the study area

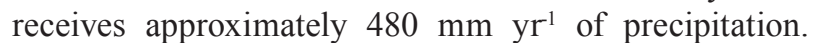
However, the amount of precipitation was quite low as well as $46.5 \mathrm{~mm}$ for the growing season (about 180 days) of cotton. The annual average, minimum and maximum, temperatures during the growing season for the study area were $13.8,0.9$ and $42.3^{\circ} \mathrm{C}$, respectively [24]. 


\section{Field Trials and Treatments}

Split plots design was used in randomized blocks with three replications in this study, including three drip irrigation systems in the main plots ( $\mathrm{I}_{1}: \mathrm{SDI}$; $\mathrm{I}_{2}$ : SSDI $(30 \mathrm{~cm})$; and $\mathrm{I}_{3}$ : SSDI $\left.(40 \mathrm{~cm})\right)$ and three $\mathrm{ET}_{\mathrm{c}}$ levels $\left(\mathrm{K}_{1}: 1.25 \times \mathrm{ET}_{\mathrm{c}}, \mathrm{K}_{2}: 1.0 \times \mathrm{ET}_{\mathrm{c}}\right.$ and $\mathrm{K}_{3}=0.75$ $\left.\times \mathrm{ET}_{\mathrm{c}}\right)$ for different irrigation water levels. The treatments in the experiment are provided in Table 1.

The area of one of the plots in the field experiment was $33.60 \mathrm{~m}^{2}(4.20 \mathrm{~m} \times 8.00 \mathrm{~m})$. Each one lateral line served for two cotton rows, thus the spacing of two laterals was $1.40 \mathrm{~m}$ considering cotton row of $70 \mathrm{~cm}$.

A 16-mm diameter polyethylene (PE) pipe (lateral pipe) with in-line drippers at each $0.40 \mathrm{~m}$, the average discharge of pressure compensated drippers was $2.2 \mathrm{~L} \mathrm{~h}^{-1}$ at the $0.1 \mathrm{MPa}$ because of the soil conditions.

\section{Estimation of Crop Evapotranspiration and Irrigation Scheduling}

For the estimation of crop evapotranspiration based on the FAO-56 PM method, the required climatological data were used from the automatic climatological station near the experimental site. Irrigation scheduling was performed at a frequency of 5 days [25] based on $E_{c}$ levels. The crop coefficient $\left(\mathrm{K}_{\mathrm{c}}\right)$ approach was used for the crop $\mathrm{ET}_{\mathrm{c}}$, and the equation given below (1) was used to calculate crop $\mathrm{ET}_{\mathrm{c}}$ [13].

$$
\mathrm{ET}_{\mathrm{c}}=\mathrm{K}_{\mathrm{c}} \times \mathrm{ET}_{\mathrm{o}}
$$

...where $\mathrm{ET}_{\mathrm{c}}$ is the estimation of crop evapotranspiration based on FAO-56 PM $\left(\mathrm{mm} \mathrm{d}^{-1}\right), \mathrm{K}_{\mathrm{c}}$ is the crop coefficient for cotton and $\mathrm{ET}_{\mathrm{o}}$ is the reference crop evapotranspiration $\left(\mathrm{mm} \mathrm{d}^{-1}\right)$.

The daily reference $\mathrm{ET}_{\text {o }}$ was calculated in a spreadsheet program using the FAO-56 PM method. $\mathrm{K}_{\mathrm{c}}$ values concerning the crop development stages (initial stage, crop development stage, boll development stage (mid-season), and maturity stage (last season) of cotton in the study area were derived/computed from the publication of FAO-56 [13] considering using the longterm climatological data in the study area (last 30 years) [26]. Thus, the $K_{c}$ values were considered to be 0.33 , $0.33-1.27,1.27$, and $1.27-0.68$ for the initial (0-30 days after sowing (DAS)) development stage (31-80 DAS), boll development (81-131 DAS), and maturity stage $(131 \mathrm{DAS}<$ ) for cotton, respectively (Fig. 1).

The volume of water was calculated [3] as the following:

$$
\mathrm{I}=\mathrm{A} \times \mathrm{ET}_{\mathrm{c}} \times \mathrm{K} \times \mathrm{P}_{\mathrm{c}}
$$

...where I is the amount of irrigation water applied to the experimental plot (liters, L), A is the plot area $\left(\mathrm{m}^{2}\right)$, $\mathrm{ET}_{\mathrm{c}}$ is the estimated crop evapotranspiration $(\mathrm{mm}), \mathrm{K}$ is

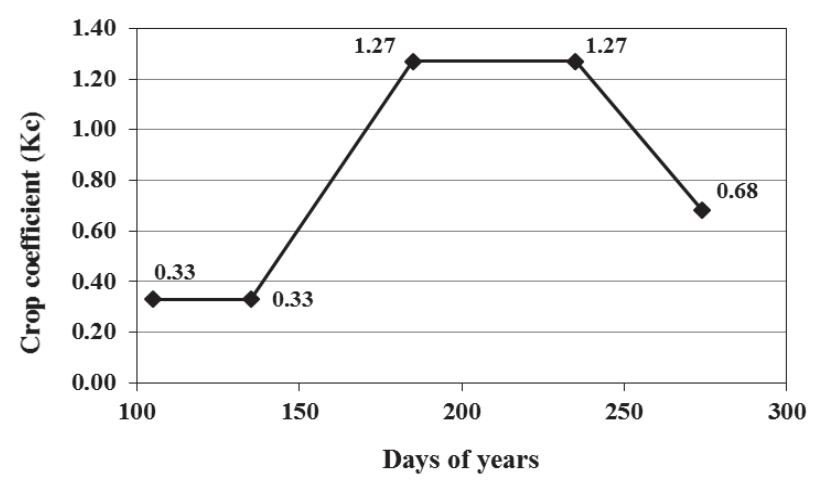

Fig. 1. Crop coefficient $(\mathrm{Kc})$ used in the calculation of irrigation water according to the FAO-56 PM in the study area for cotton [26].

the different rates of $\mathrm{ET}_{\mathrm{c}}$ according to the treatments, and $\mathrm{P}_{\mathrm{c}}$ is the canopy cover (\%). Canopy cover was used to calculate the amount of water applied in this study in case the whole soil surface should not be irrigated/ wetted depending on the development of canopy cover. This was considerably important at the beginning of the growing season [3].

The percentage of crop canopy cover was computed before each irrigation cycle by measuring using a simple wooden device $(70 \mathrm{~cm} \times 100 \mathrm{~cm})$ divided into 100 equal sections. The crop canopy coverage, thus, calculated by measuring the average crop width in a row and dividing that value by the crop bed width (row space). Thus, the development of plant canopy as numerical value was calculated by dividing canopy wide to plant row space [27]. The crop canopy cover values, $\mathrm{P}$, of $35 \%$ were used until the value exceeded $35 \%$. When the Pc exceeded $35 \%$, the actual measured values were taken into account for each treatment and the other irrigation cycles [3].

The first irrigation was performed to bring to the field capacity a level of soil depth of $60 \mathrm{~cm}$ for all the treatments/plots; thus, the same amount of water was applied to all the plots. Then, the treatments (different amounts of irrigation water) based on FAO-56 PM were applied considering an irrigation interval of 5 days. Irrigation continued according to treatments until the beginning of September when approximately $10 \%$ of bolls on the plants were fully open.

\section{Measurement of the Soil Moisture and Actual Evapotranspiration}

Soil moisture level was measured before and after each irrigation cycle using soil moisture sensors (Decagon, Procheck) for each treatment and considering soil depths of 30,60 and $90 \mathrm{~cm}$. In addition, the gravimetric method was used in order to check soil moisture sensors from time to time.

To determine the actual crop evapotranspiration in the field plots, the water balance equation was used considering a soil depth of $90 \mathrm{~cm}$ [13]. 
Table 1. Experimental treatments according to the split plots in randomized blocks.

\begin{tabular}{|c|c|}
\hline Main plots (Different drip irrigation systems) & Sub-plots (Different amount of irrigation water) \\
\hline $\mathrm{I}_{1}:$ Surface drip irrigation & $\mathrm{K}_{1}: \mathrm{I}=1.25 \mathrm{x}$ ETc \\
\hline $\mathrm{I}_{2}:$ Subsurface drip irrigation $($ depth of $30 \mathrm{~cm})$ & $\mathrm{K}_{2}: \mathrm{I}=1.0 \times \mathrm{x}$ ) \\
\hline $\mathrm{I}_{3}:$ Subsurface drip irrigation $($ depth of $40 \mathrm{~cm})$ & $\mathrm{K}_{3}: \mathrm{I}=0.75 \times \mathrm{xEc}$ \\
\hline
\end{tabular}

$$
\mathrm{P}+\mathrm{I}=\mathrm{ET}_{\mathrm{a}}+\mathrm{R}+\mathrm{D}+\mathrm{C} \pm \mathrm{S}
$$

...where $\mathrm{P}$ is the precipitation ( $\mathrm{mm}), \mathrm{I}$ is the amount of irrigation water applied(mm), ET is the actual crop evapotranspiration $(\mathrm{mm}), \mathrm{R}$ is the runoff $(\mathrm{mm}), \mathrm{D}$ is deep percolation $(\mathrm{mm}), \mathrm{C}$ is capillary rise $(\mathrm{mm})$, and $\mathrm{S}$ is the soil moisture change ( $\mathrm{mm})$.

In this equation, the precipitation data was provided from an automatic climatic station near the study area. The precipitation occurred only at the beginning of growing season and there were no more than $10 \mathrm{~mm}$ for each precipitation event. There was some deep percolation in the treatment of $1.25 \mathrm{xET}_{\mathrm{c}}$ in 2017. In addition, there was not runoff. The capillary rise was negligible because there was not any water table in the soil profile.

\section{Agricultural Applications}

Cotton seeds (Gossypium hirsutum cv. ST 468) were sown with a spacing of $20 \mathrm{~cm} \times 70 \mathrm{~cm}$ on May 11 and 9, 2016 and 2017, respectively. All fertilizers were applied according to the previous studies' results in the study region [3]. The total amounts of nitrogen (N) and phosphorus (P) were $130 \mathrm{~N} \mathrm{~kg} \mathrm{ha-1} \mathrm{and}$ $80 \mathrm{P}_{2} \mathrm{O}_{5} \mathrm{~kg} \mathrm{ha}^{-1}$, respectively [28]. One-fifth of the $\mathrm{N}$ and $\mathrm{P}$ was applied to the experimental plots before cotton seed sowing [29]. Application of the rest of the fertilizers was applied by fertigation. Fertigation was implemented at the first irrigation and continued throughout the boll formation stage at each of the two irrigation cycles [25]. The fertilizer used at the fertigation application was a mix of N, P, and potassium at 19-5-5. Fertigation was applied using a fertilizer by-pass tank employing the pressure difference method [11, 25].

The seed cotton harvested by hand in the central four rows of each subplot two times during the cropping seasons: the first harvest was made at about $80 \%$ of the opened bolls, and the second harvest was made for the rest of opened bolls at the beginning of September and end of September, respectively. Thus, the size of the sowing area was $4.20 \mathrm{~m} \times 8.00 \mathrm{~m}\left(33.60 \mathrm{~m}^{2}\right)$. The harvesting area is $15.6 \mathrm{~m}^{2}(2.8 \mathrm{~m} \times 6.00 \mathrm{~m})$. The obtained yields from the harvesting area were converted to the unit land area (ha) for all the calculations and evaluations.

\section{Statistical Evaluation and Analysis}

The yield and other data were analyzed through the analysis of variance (ANOVA) using the SPSS software
(Version 16.0.0). In the event that the results obtained from statistical analysis were statistically significant, a Duncan's multiple range test was applied to determine and to evaluate the differences among the means of treatments [30].

\section{Results and Discussion}

\section{Seed Cotton Yields Under The Different Drip Irrigation Systems}

Seed cotton yield obtained from each treatment according to the experimental years are given in Table 2. The yields obtained from the experiment ranged from 2520 to $5214 \mathrm{~kg} \mathrm{ha}^{-1}$ depending on the experimental years and the treatments.

It was observed that during 2016, no statistical difference were found on yields for both drip irrigation systems and the interaction of drip irrigation systems together with different amounts of irrigation levels based on $\mathrm{ET}_{\mathrm{c}}$. However, SSDI in the lateral depth of $40 \mathrm{~cm}$ resulted in considerably more yield (Tables 2 and 3). Considering the different amount of irrigation levels based on $\mathrm{ET}_{\mathrm{c}}$, the seed cotton yields were significantly different $(\mathrm{p} \leq 0.01)$.

In 2017, there were significant differences between drip irrigation systems $(p \leq 0.05)$ and the amount of irrigation water applied $(p \leq 0.01)$ on seed cotton yield. No significant effect on the interaction was found between different amounts of irrigation water applied and different drip irrigation systems, as it occurred in 2016.

Seed cotton yields, based on both the amount of irrigation water and drip irrigation systems, are provided separately in Table 3 because there was no significant interaction between the treatments. In each of the two experimental years, the seed cotton yields increased as long as there was an increase in the amount of irrigation water, regardless of the type of drip irrigation systems. However, SSDI, especially in the depth of $40 \mathrm{~cm}$, resulted in the highest yield considering all the experimental years.

The main reasons for increasing the seed cotton yield by means of increasing irrigation water for all the drip irrigation systems in this study could be that the plants in hot and dry areas use more water to both cool off and produce more biomass [19]. Increasing irrigation water for all the drip irrigation systems were the increase in the number of good opened bolls and 
Table 2. Seed cotton yield $\left(\mathrm{kg} \mathrm{ha}^{-1}\right)$ and amount of irrigation water applied $(\mathrm{mm})$ according to the experimental years and the treatments.

\begin{tabular}{|c|c|c|c|c|c|c|c|c|}
\hline \multirow{3}{*}{ Main plots } & \multirow{3}{*}{ Subplots } & \multirow{2}{*}{\multicolumn{2}{|c|}{ 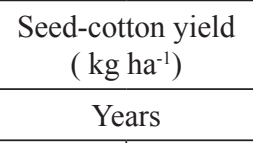 }} & \multirow{3}{*}{$\begin{array}{l}\text { Average yield } \\
\quad\left(\mathrm{kg} \mathrm{ha}^{-1}\right)\end{array}$} & \multirow{2}{*}{\multicolumn{2}{|c|}{$\begin{array}{c}\text { Amount of irrigation } \\
\text { water applied }(\mathrm{mm}) \\
\text { Years }\end{array}$}} & \multirow{3}{*}{$\begin{array}{c}\text { Average } \\
\text { irrigation water } \\
(\mathrm{mm})\end{array}$} & \multirow{3}{*}{$\begin{array}{l}\mathrm{WP}_{\mathrm{Irr}} \\
\left(\mathrm{kg} \mathrm{m}^{-3}\right)\end{array}$} \\
\hline & & & & & & & & \\
\hline & & 2016 & 2017 & & 2016 & 2017 & & \\
\hline \multirow{3}{*}{$\mathrm{I}_{1}$} & $\mathrm{~K}_{1}$ & 4139 & 4624 & 4382 & 606.2 & 675.9 & 641.1 & 0.68 \\
\hline & $\mathrm{K}_{2}$ & 4191 & 3972 & 4082 & 458.1 & 517.6 & 487.9 & 0.84 \\
\hline & $\mathrm{K}_{3}$ & 2558 & 2520 & 2539 & 310.2 & 303.1 & 306.7 & 0.83 \\
\hline \multirow{3}{*}{$\mathrm{I}_{2}$} & $\mathrm{~K}_{1}$ & 4286 & 5214 & 4750 & 604.6 & 676 & 640.3 & 0.74 \\
\hline & $\mathrm{K}_{2}$ & 3862 & 4197 & 4030 & 540.2 & 522.6 & 531.4 & 0.76 \\
\hline & $\mathrm{K}_{3}$ & 2741 & 3016 & 2879 & 337.8 & 364.1 & 351.0 & 0.82 \\
\hline \multirow{3}{*}{$\mathrm{I}_{3}$} & $\mathrm{~K}_{1}$ & 4332 & 5184 & 4758 & 661.5 & 685.8 & 673.7 & 0.71 \\
\hline & $\mathrm{K}_{2}$ & 4268 & 4687 & 4478 & 543.9 & 558.7 & 551.3 & 0.81 \\
\hline & $\mathrm{K}_{3}$ & 3819 & 3646 & 3733 & 363.2 & 375.6 & 369.4 & 1.01 \\
\hline
\end{tabular}

Coefficient of variation (CV): $12.5 \%$ in 2016 and $11.1 \%$ in 2017

the total number of bolls produced per plant $[3,9,31]$. Concerning the highest seed cotton yield provided by SSDI, the evaporation from the soil is decreased by decreasing top soil moisture content because the drip laterals are under the soil surface [14, 19, 32]. Thus, the loss of irrigation water due to evaporation was insignificant and the plants used more water and it provided increasing seed cotton yield. The volume of wetted soil in SSDI might be, thus, bigger (spherical) than in SDI (hemi-spherical). The available water and soil volume for crop root development could be also bigger, whereas the wetted radius was smaller in SDI than in SSDI [14] and (Fig. 2).

The scheduling of irrigation at $1.25 \times \mathrm{ET}_{\mathrm{c}}$ with a 40-cm SSDI recorded a significantly higher seed cotton yield in both 2016 and 2017 (Table 2). Azevedo et al. [33] reported that irrigation with $120 \%$ of that crop evapotranspiration under sprinkler irrigation produced the maximum seed cotton yield. Moreover, Shruti and Aladakatti [34] determined a significantly higher seed-cotton yield $\left(4024 \mathrm{~kg} \mathrm{ha}^{-1}\right)$ in drip irrigation at $1.0 \times \mathrm{ET}_{\mathrm{c}}$. The SSDI, regardless of the amount of irrigation water, resulted in an increase of $18 \%$ and $11 \%$ over SSDI-30 cm and SDI, respectively (Fig. 3). Kalfountzos et al. [7] and Roopashree et al. [9] also found similar results.

The reason that the maximum yield was obtained in the SSDI system $(40 \mathrm{~cm})$ might be attributed to the controlled and/or preferable quantity of water applied directly to the root zone in quantities, which move toward the use of plant consumption by means of SSDI. In addition, a higher irrigation coefficient $\left(\mathrm{K}_{1}\right.$ and $\left.\mathrm{K}_{2}\right)$ caused more amount of irrigation water applied and this increased also canopy cover. Thus, the yield was obtained much more higher depending on increasing canopy cover (Fig. 4). However, the evaporation losses from the soil surface on the SDI were much more than SSDI $[8,19,22]$. Thus, the use of SSDI on cotton increased dramatically, especially in areas with water shortages [7, 15, 17, 18, 22]. In addition, the main reason of that the installation depth of emitter and lateral line for $0.40 \mathrm{~m}$ was more appropriate could be that cotton plant roots would grow through relatively dry soil to find moisture in the soil at deeper soil depths.

Table 3. The separately effects of the different drip irrigation systems and different amount of irrigation water on seed-cotton yield $\left(\mathrm{kg} \mathrm{ha}^{-1}\right)$.

\begin{tabular}{|c|c|c|c|c|c|c|c|c|c|}
\hline $\begin{array}{c}\text { Drip irrigation } \\
\text { systems }\end{array}$ & 2016 & 2017 & Ave. & $\begin{array}{c}\text { Relative yield level } \\
(\%)\end{array}$ & Irr. levels & 2016 & 2017 & $\begin{array}{c}\text { Ave. } \\
\text { Relative yield } \\
(\%)\end{array}$ \\
\hline $\mathrm{I}_{1}$ & $3629 \mathrm{~b}^{*}$ & $3705 \mathrm{~b}$ & $3667 \mathrm{~b}$ & 84.8 & $\mathrm{~K}_{1}$ & $4252 \mathrm{a}$ & $5007 \mathrm{a}$ & 4630 & 100 \\
\hline $\mathrm{I}_{2}$ & $3630 \mathrm{~b}$ & $4142 \mathrm{ab}$ & $3886 \mathrm{ab}$ & 89.8 & $\mathrm{~K}_{2}$ & $4107 \mathrm{a}$ & $4285 \mathrm{~b}$ & 4196 & 90.6 \\
\hline $\mathrm{I}_{3}$ & $4140 \mathrm{a}$ & $4506 \mathrm{a}$ & $4323 \mathrm{a}$ & 100 & $\mathrm{~K}_{3}$ & $3039 \mathrm{~b}$ & $3061 \mathrm{c}$ & 3050 & 65.8 \\
\hline
\end{tabular}

$\mathrm{I}_{1}$ : Surface drip irrigation (SDI), $\mathrm{I}_{2}$ : Subsurface drip irrigation $(\mathrm{SSDI}-30 \mathrm{~cm}), \mathrm{I}_{3}$ : Subsurface drip irrigation $(\mathrm{SSDI}-40 \mathrm{~cm}), \mathrm{K}_{1}$ : $1.25 \mathrm{xETc}, \mathrm{K}_{2}: 1.00 \mathrm{xETc} . \mathrm{K}_{3}: 0.75 \mathrm{xETc}$

*: The same letter groups are not the statistically significant according to the Duncan's multiple comparison test. 


\section{SURFACE DRIP IRRIGATION}

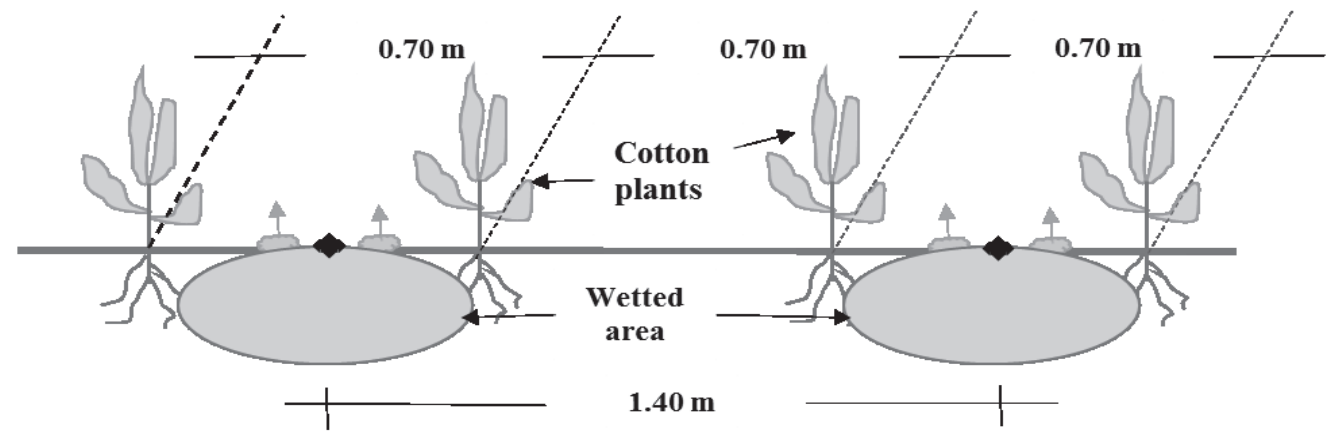

SUBSURFACE DRIP IRRIGATION

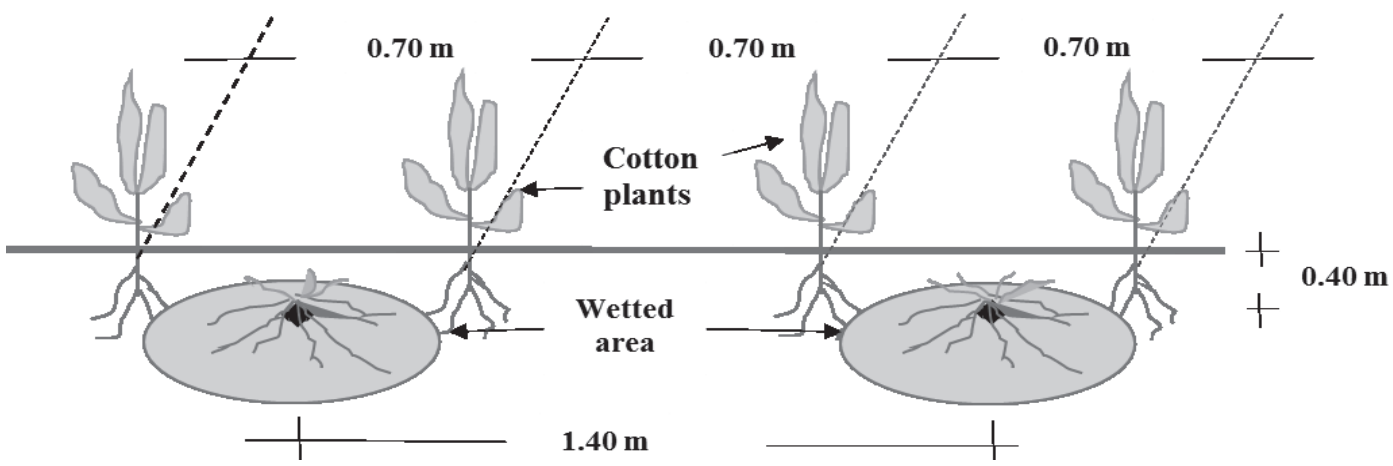

Fig. 2. Shematic layout of laterals and drippers in surface and subsurface drip irrigation and soil moisture distribution depending on drip lateral spaces and depth of subsurface drip irrigation.

This system was, thus, more effective in meeting the maximum evapotranspiration demands of cotton and in pushing salt to the edge of the bed.

\section{Irrigation Water Use and Crop \\ Evapotranspiration}

The amounts of irrigation water applied according to the treatments in the experiment varied from
$310.2 \mathrm{~mm}$ to $661.5 \mathrm{~mm}$ in 2016 and from $303.1 \mathrm{~mm}$ to $685.8 \mathrm{~mm}$ in 2017 (Table 2). The number of irrigation in 2016 was 17 and/or 18 based on the irrigation intervals of 5 days, and depending on the treatments. Considering the calculation of the amount of irrigation water for each treatment and its components, the amount of irrigation water applied was different as dependent on the coefficients of Etc, the development of canopy cover, and the physiological maturity date of crops.
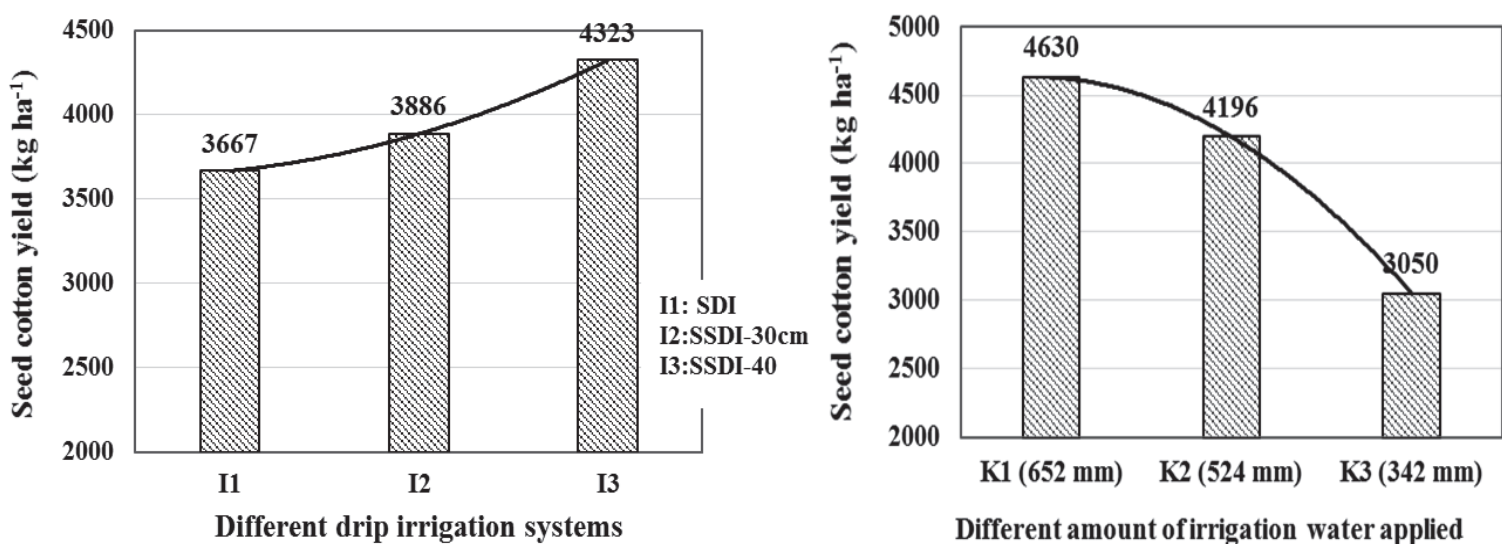

Different amount of irrigation water applied (mm)

Fig. 3. The effects of the different drip irrigation systems and different amount of irrigation water on seed- cotton yield. (SDI: Surface drip irrigation, SSDI: Sub-surface drip irrigation). 
In general, SSDI-40 cm received relatively more irrigation water because the development of canopy cover in SSDI-40 $\mathrm{cm}$ was rapid compared to the other treatments, and the calculation of irrigation water was also dependent on the canopy cover (Equation 2). Because the plant canopy factor used for all treatments was the percentage area covered by plant canopy (foliage). The canopy cover gradually expanded and in the following days or crop development stages, canopy cover rapidly increased [27]. The higher irrigation coefficient $\left(\mathrm{K}_{1}\right.$ and $\left.\mathrm{K}_{2}\right)$ resulted in more amount of irrigation water and this increased canopy cover.

On the other hand, according to the previous studies, the number of bolls and cotton production decreased as long as the irrigation water decreased (stress conditions) $[3,5,35]$. Thus, it was also reported that seed cotton yield were positively affected by increased irrigation amounts. Deficit irrigation resulted in $27-29 \%$ in biomass, 16-28 \% in seed yield depending on different cotton varieties [31].

Considering the average seed-cotton yields, there was a linear relationships between seed-cotton yield and irrigation water for SDI: $y=987+5.6 x$, $\mathrm{R}^{2}=0.90^{* *}, \mathrm{P} \leq 0.01$; for SSDI-30 cm: $y=608.8+6.45 x$, $\mathrm{R}^{2}=0.99 * *, \mathrm{P} \leq 0.01$; and for SSDI-40 cm: $y=2502.8$ $+3.42 x, \mathrm{R}^{2}=0.98^{* *}, \mathrm{P} \leq 0.01$. Where $y$ is seed cotton yield ( $\mathrm{kg} \mathrm{ha}^{-1}$ and $x$ is amount of irrigation water $(\mathrm{mm})$.

The reference evapotranspiration (ET) according to the experimental years for the growing season of cotton was computed as $627.7 \mathrm{~mm}$ and $622.5 \mathrm{~mm}$ in 2016 and 2017, respectively. The values of $\mathrm{ET}_{\mathrm{o}}$ in the experimental years were quite close to each other. The actual measured $\mathrm{ET}_{\mathrm{a}}$ was calculated using the water budget equation (Equation 3). The actual $\mathrm{ET}_{\mathrm{a}}$ ranged from 349.4 to $697.1 \mathrm{~mm}$ in 2017 and from 312.6 to $701.1 \mathrm{~mm}$ in 2017 depending on the treatments, respectively. The most important input for the determination of the actual $\mathrm{ET}_{\text {a }}$ was the amount of irrigation water applied because there was no significant precipitation during the growing season. However, the precipitation of 44.8 and $19.4 \mathrm{~mm}$ occurred at the beginning of the growing season in 2016 and 2017, respectively. In another study, the average ETc during the growing season for drip irrigated cotton was 526 $\mathrm{mm}$ in Northwestern China. Thus, the fluctuation in daily crop evapotranspiration was attributed to variation in cotton leaves [36]. Evett et al. [37] compared the SDI and SSDI systems for the corn crop, and the insignificant differences occurred on the soil heat flux between SDI and SSDI. The net radiation on the SDI increased as much as the leaf area index of 4.2 compared to that of the SSDI; however sensible heat was smaller. There were differences in ETa between SDI and SSDI for only during the partial development of the crop canopy. Thus, there was almost no difference in ETa under the canopy cover were $100 \%$. In this study, the crop ETa on SDI was lower than that on SSDI because crop development and canopy cover in SSDI were much more than those in SDI.
The amount of irrigation water applied increased as long as increasing rates of estimated crop ET based on FAO-56 PM. Thus, the actual ET increased even if SSDI systems were used. The main reason for the increases in the evapotranspiration could be attributed to the climatic conditions during the experiment in the study area because the maximum temperatures $\left(40.5^{\circ} \mathrm{C}\right)$ and wind speed $\left(4.4 \mathrm{~m} \mathrm{sec}^{-1}\right)$ were significantly high and the average relative humidity (20.7\%) in summer was quite low [24]. In particular, the evaporation from the soil surface was much higher at the stage of the crop canopy, which had not covered the entire soil surface, as well as the stage of vegetative development [Fig. 4]. It might be stated that this could restrict the utilization of crop root per unit water.

Regarding water use, the horizontal movement of water in the SDI was more than that in the SSDI because the irrigation water in SDI was applied directly to the soil surface and the soil texture was heavy clay (clay content is about 65\%). In particular, the wetted area in the period between sowing and before the canopy cover of $100 \%$ could be exposed to the sun radiation in SDI; thus, this circumstance could increase evaporation from the soil (Fig. 4). Hence, the efficient use of water could be decreased by crops in SDI [38]. On the other hand, it was reported that the evaporation loss from the soil could be decreased by using SSDI [8, $15,23]$.

Another finding in this study was that irrigation water productivity (IWP) increased as long as a decreased amount of irrigation water was applied (Table 2). Similar results were found by Keten [39]. This might be attributed to a much higher response of the crop to the water since the study area has a very high temperature and a very low relative humidity during the growing season.

Considering the drip irrigation systems, IWP for SDI, SSDI-30 cm, and SSDI-40 were 0.78, 0.77, and $0.84 \mathrm{~kg} \mathrm{~m}^{-3}$, respectively. Thus, the highest IWP was obtained from the treatment of SSDI-40 cm (Table 2). Similarly, various studies on IWP showed that SSDI resulted in the highest IWP for cotton $[6,8,40]$.

Regarding the actual measured crop evapotranspiration, evaporation from the soil is especially dependent on the content of water on the soil surface and the rate of canopy cover [41]. Thus, canopy cover is significantly important for crop evapotranspiration and calculating the amount of irrigation water applied for the drip irrigation methods. For this, evaporation from the soil decreases as long as the canopy cover of the crop and/or vegetative development increases (Fig. 4).

Evaporation from the soil after the irrigation event is high; however, it quickly decreases as long as the soil surface dries after the first wetted period of the soil (Fig. 4). Thus, crop evapotranspiration, under the condition wherein part of the soil surface is covered by plant canopy, is lower than under the condition wherein the whole soil surface is covered by plant canopy [13, 


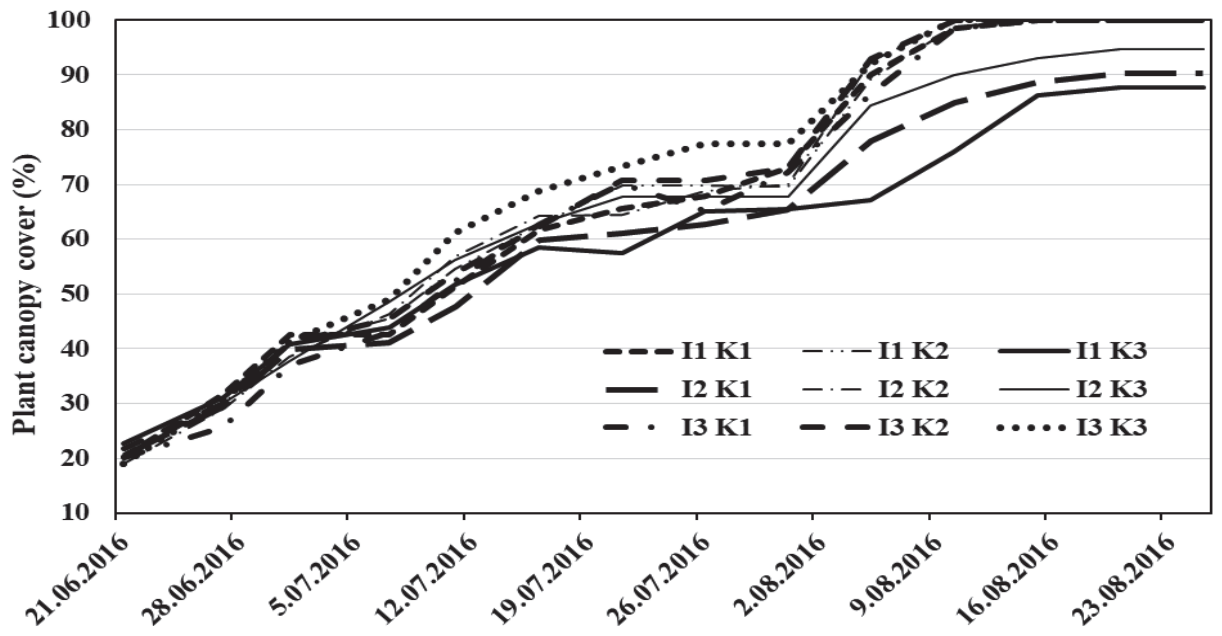

Crop development stage

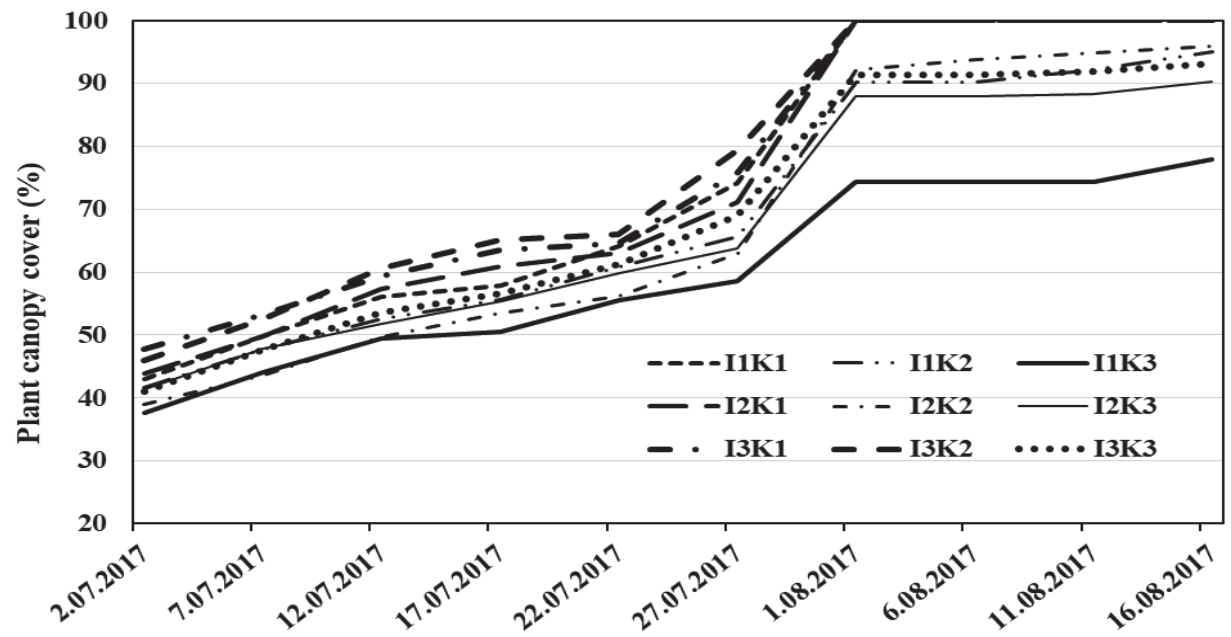

Crop development stage

Fig. 4. Development of canopy cover as percentage according to the treatments (surface and subsurface drip irrigation, and different amount of irrigation water) and experimental years. ( $\mathrm{I}_{1}$ : Surface drip irrigation $(\mathrm{SDI}), \mathrm{I}_{2}$ : Subsurface drip irrigation $(\mathrm{SSDI}-30 \mathrm{~cm}), \mathrm{I}_{3}$ : Subsurface drip irrigation (SSDI-40 cm), $\mathrm{K}_{1}: 1.25 x E T c, \mathrm{~K}_{2}: 1.00 x E T c . \mathrm{K}_{3}: 0.75 x E T c$.

14, 42]. However, crop evapotranspiration could be decreased by surface and subsurface drip irrigation against surface irrigation (border and furrow) was mainly due to the significant reduction in evaporation [43]

\section{Total Water Use and Net Income For Cultivated Cotton Region}

In this part of the article, some projections on total water use, water productivity and economic incomes was made using the regression equations obtained from the research results for the cultivated cotton area. For furrow irrigation, the results of the previous research [3] in the same study region was based on for the calculations. Accordingly, the sub-surface drip irrigation in the depth of $40 \mathrm{~cm}$ instead of it in the depth of $30 \mathrm{~cm}$ was preferred because of tillage problems and some damage risk in the dripper lines in $30 \mathrm{~cm}$.
The calculations given in Table 4 were realized based on the following equations, furrow irrigation: $\mathrm{y}=-431.1+6.1 \mathrm{x}-0.0021 \mathrm{x}^{2}[3]$, SDI: $\mathrm{y}=987+5.6 \mathrm{x}$ and SSDI-40 cm: $y=2502.8+3.42 x$. The amount of irrigation water was computed using the regression equations for the almost same seed cotton yield obtained by drip irrigation methods and the optimum yield in furrow irrigation. Accordingly the other estimated calculations and comparison were realized.

According to the evaluations given in Table 4, surface and sub-surface drip irrigation saved about 37 and $42 \%$ compared to furrow irrigation, respectively. Subsurface drip irrigation saved also water of $9 \%$ compared to surface drip irrigation. This difference is very important and quite high compared to furrow irrigation. Some previous studies have been also reported that drip irrigation have already provided significant water savings compared to surface irrigation [3, 8, 44, 45]. In addition, Rao et al. [46 ] reported similar result in our 


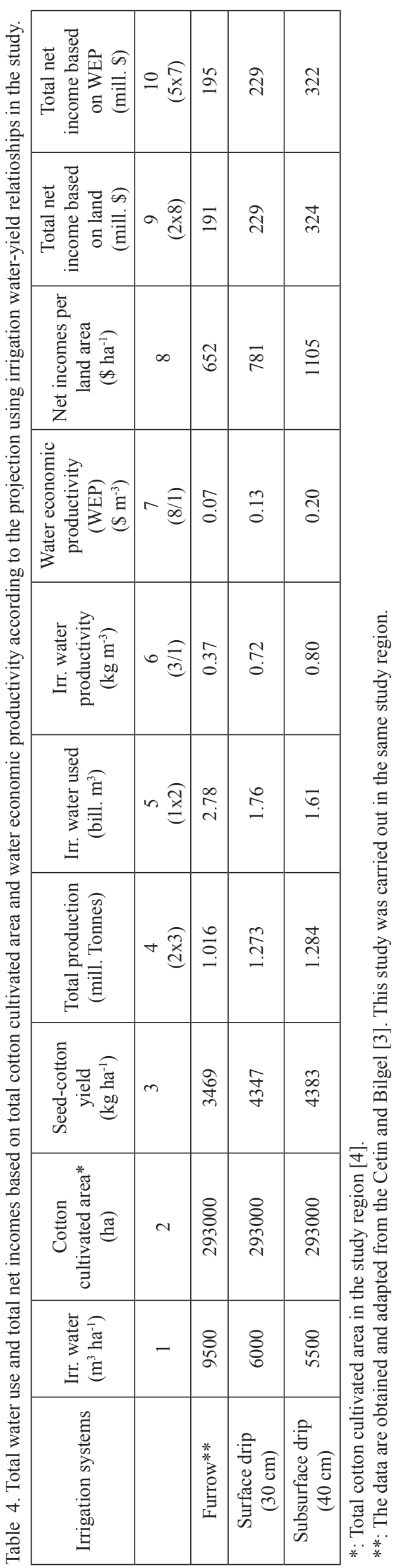

study that drip irrigation significantly increased seed cotton yield by $33.5 \%$ and saved $30 \%$ irrigation water compared to furrow irrigation at $1.0 \mathrm{x}$ ETc for cotton. In another study, drip irrigation provided more yield of $24 \%$ in seed cotton yield at $100 \%$ ETc compared to furrow irrigation. [47]. Net income based on unit area in surface and subsurface irrigation was higher 20 and $69 \%$ than it in furrow irrigation, respectively (Table 4). Therefore, this result is also valid for the total income in the study region. Irrigation water productivity in furrow irrigation was very low compared to surface and subsurface drip irrigation. The main reason for this was to use much more irrigation water in furrow irrigation and lower yield was obtained. Considering the total income based on the water economic productivity in furrow irrigation was higher than it in the surface drip. Although this seems to be inconsistent with other previous calculation results, this occurred due to the use of more irrigation water in furrow irrigation.

The results of this study will be important for irrigation management, irrigation water saving, water productivity $\left(\mathrm{kg} \mathrm{m}^{-3}\right)$, water economic productivity $\left(\$ \mathrm{~m}^{-3}\right)$ and net income per unit area $\left(\$ \mathrm{ha}^{-1}\right)$ in case of use of different irrigation methods and/or systems. Thus, these comparisons will be useful in terms of policy making on irrigation management for decision makers [48, 49]. Probably, it will not be possible to irrigate all cotton cultivated areas using drip irrigation systems. However, these data based on these scientific results can be considered alternatively in case of drought and water insufficiency and all these can be also used to compensate and/or support the famers in case of the income and production losses.

As a result, it has been determined that the use of drip irrigation systems (especially subsurface drip) is significantly important considering possible water shortage, decreasing water resources, farmers, irrigation schemes, regional and national incomes. However, it should not be paid insufficient attention on the necessary engineering approaches for the irrigation systems, appropriate irrigation management and operation taking into account the soil, crop and climate characteristics in the irrigated area. In this case, all advantages of drip irrigation systems can be realized.

\section{Conclusions}

It was concluded that the SSDI method at $1.0 \times \mathrm{ET}_{\mathrm{c}}$ was proven to be optimum and resulted in recording higher seed-cotton yield and water saving in comparison to the SDI method. SSDI resulted in much more seed cotton yield compared to SDI in every case. Thus, there were statistically significant $(p \leq 0.01)$ seed cotton yield differences, as much as $18 \%$ (657 $\mathrm{kg} \mathrm{ha}^{-1}$ ), between SSDI (the lateral depth of $40 \mathrm{~cm}$, which is recommendable) (4323 kg ha-1) and SDI $\left(3667 \mathrm{~kg} \mathrm{ha}^{-1}\right)$. The seasonal actual evapotranspiration and amount of irrigation water in SSDI were 589 and 
$552 \mathrm{~mm}$, respectively. According to the projections and comparing the previous study in the same study region [3], surface and sub-surface drip irrigation saved about 37 and $42 \%$ compared to furrow irrigation, respectively. However, net income based on unit area in surface and subsurface irrigation was higher 20 and $69 \%$ than it in furrow irrigation, respectively. The use of $30 \mathrm{~cm}$ at the lateral depth for SSDI has created some soil plough problems in terms of damaging the system; thus, this lateral depth should not be used for SSDI construction for cotton irrigation. Irrigation scheduling based on real crop evapotranspiration was more appropriate for water saving and increasing water productivity.

The use of drip irrigation systems (especially subsurface drip) is significantly important considering possible water shortage, decreasing water resources, farmers, irrigation schemes, regional and national incomes.

On the other hand, the wetted percentage area and/ or canopy cover is one of the most important criteria in irrigation water calculation for drip irrigation systems. It could be recommended to be as much as $40 \%$ at the beginning of the irrigation season for arid regions, as in the study area, which had very low relative humidity $(10-15 \%)$ and very high temperatures (up to $45^{\circ} \mathrm{C}$ ). In addition, the percentage of canopy cover used to calculate the amount of water applied should be set from the first irrigation until the canopy cover exceeds $40 \%$, after which it should be set to the measured value until the last irrigation. However, the value of the canopy cover used to calculate the amount of water applied might be considered to be $80 \%$ (0.80) during the maturity stage, that is, from the opening stage of the first bolls to the last irrigation (approximately 2-3 weeks).

\section{Acknowledgements}

The data in this article is taken from the final report of the project supported by the Scientific and Technological Research Council of Turkey (TUBITAK). (Grant number: 1150600). Thus, we would like to thank TUBITAK. In addition, some different articles were published using different data from the same project report. Therefore, only some of parts of the "material and method" in the articles are similar.

\section{Conflict of Interest}

The authors declare no conflict of interest.

\section{References}

1. D'ODORICO P., CHIARELLI D.D., ROSA L., BINI A., ZILBERMAN D., RULLI M.C. The global value of water in agriculture. PNAS 117 (36), 21985, 2020.
2. DSI. Soil and water resources. State Hydraulic Works, Available online, http://www.dsi.gov.tr (accessed on 28 May 2019).

3. ÇETIN Ö., BILGEL L. Effects of different irrigation methods on shedding and yield of cotton. Agricultural Water Management, 54, 1, 2002.

4. TUIK. Cotton bulletin. Turkish Statistical Institute. www.tarimorman.gov.tr/BUGEM (accessed date on 23 November 2020)

5. ÜNLÜ M., KANBER R., KAPUR B., TEKIN S., KOC D.L. The crop water stress index (cwsi) for drip irrigated cotton in a semi-arid region of Turkey. African Journal of Biotechnology, 10 (12), 2258, 2011.

6. JAYAKUMAR M., SURENDRAN U., MANICKASUNDARAM P. Drip fertigation program on growth, crop productivity, water, and fertilizer-use efficiency of Bt cotton in semi-arid tropical region of India. Communications in Soil Science and Plant Analysis, 46, 293, 2015.

7. KALFOUNTZOS D., ALEXIOU I., KOTSOPOULOS S., ZAVAKOS G., VYRLAS P. Effect of sub surface drip irrigation on cotton plantations. Water Resources Management, 21, 1341, 2007.

8. MARTÍNEZ J., RECA J. Water use efficiency of surface drip irrigation versus an alternative subsurface drip irrigation method. Journal of Irrigation and Drainage Engineering, 140 (10), 04014030, 2014.

9. ROOPASHREE M., RAJKUMARA S., NEELAKANTH J.K. Effect of surface and sub-surface drip irrigation at different etc levels on growth and yield of Bt cotton (Gossypium hirsutum L.). Journal of Farm Science, 29 (4), 456, 2016.

10. YAZAR A., SEZEN S.M., SESVEREN S. LEPA and trickle irrigation of cotton in Southeast Anatolia Project (GAP) area in Turkey. Agricultural Water Management, 54 (3), 189, 2002.

11. CETIN O., AKALP E. Efficient use of water and fertilizers in irrigated agriculture, drip irrigation and fertigation. Acta Horticulturae et Regiotecturae 2, 97, 2019.

12. WANG Y., LI S., QIN S., GUO H., YANG D., LAM H.M. How can drip irrigation save water and reduce evapotranspiration compared to border irrigation in arid regions in northwest China. Agricultural Water Management, 239, 106256, 2020.

13. ALLEN R.G., PEREIRA L.S., RAES D., SMITH M. Crop Evapotranspiration, Guidelines For Computing Crop Water Requirement. United Nations Food and Agriculture Organization, Irrigation and Drainage Paper 56, Rome, 1998.

14. EVETT S.R., COLAIZZI P.D., HOWELL T.A. Drip and evaporation. In, Proceedings of the Central Plains Irrigation Conference, February 16-17, 2005, Sterling, Colorado. 33, 2005.

15. LI S., WANG Z., LI S., GAO Y., TIAN X. Effect of plastic sheet mulch, wheat straw mulch, and maize growth on water loss by evaporation in dryland areas of China. Agricultural Water Management, 116, 39, 2013.

16. TUNALI S.F., GURBUZ T., DAGDELEN, N., YORULMAZ, A. The effects of different drip irrigation levels and seed-coated techniques on yield and water use efficiency of cotton. Journal of Scientific and Engineering Research, 7 (6), 62, 2020.

17. HANSON B.R., FIPPS G., MARTIN E.C. Drip irrigation of row crops, What is the state of the art? Proceeding of 4th Decennial National Irrigation Symposium Nov. 14-16, St. Joseph, Mich., ASAE, 391, 2000. 
18. LANSFORD V.D., SEGARRA E., BORDOVSKY J.P. The Dollars and cents of subsurface drip irrigation (sdi) for cotton in the southern high plains of Texas. Proceedings of Beltwide Cotton Conference, Memphis, Tenn., National Cotton Council. 2004.

19. FARAHANI H., MUNK D. Why irrigate cotton ? Cotton Irrigation Management for Humid Regions. (Eds. C. Perry, E. Barbes). America's Cotton Producers And Importers. Service Mark/Trademarks of Cotton Incorporated, 2012.

20. ŞEN S., KORKMAZ N., GÜNDÜZ M., KAYAM Y., BILI. L., AŞIK Ş., AVCI M. Irrigation scheduling of cotton and corn irrigated by subsurface drip irrigation. Yearbook, International Agricultural Research and Training Center, Menemen, İzmir, Turkey, 2013 [In Turkish].

21. ABDELGADIR A.H., FULTON J.P., DOUGHERTY M., CURTIS L.M., VAN SANTEN E., BURMESTER C.H., HARKINS H.D., NORRIS B.E. Subsurface drip irrigation placement and cotton irrigation water requirement in the Tennessee Valley. Crop Management, 10 (1), 1, 2011.

22. WU N., YANG C., LUO Y., SUN L. Estimating evapotranspiration and its components in cotton fields under deficit irrigation conditions. Polish Journal of Environmental Studies, 28 (1), 393, 2019.

23. KAMILOV B., INRAHIMOV N., ESENBEKOV Y., EVETT S., HENG L. Drip irrigated cotton, Irrigation scheduling study by use of soil mositure neutron probe. International Water and Irrigation, 23 (1), 38, 2003.

24. DMI. Statistics on meteorological data. Turkish State Meteorological Service https://www.mgm.gov.tr (Accessed date, 15.11 .2020 )

25. ÜZEN N., ÇETIN Ö. Effects of nitrogen fertigation frequency on yield and nitrogen retention in drip-irrigated cotton. Journal of Plant Nutrition, 39 (14), 2126, 2016.

26. TAGEM. Crop water evapotranspiration guide of crop irrigated in turkey. General Directorate of Agricultural Research and Policies. Ankara, Turkey, 2017 [In Turkish].

27. ÇETIN Ö., UYGAN D., BOYACI H. Tomato irrigation scheduling improved by using percent canopy cover and crop developmental stage. Australian Journal of Agricultural Research, 59 (12), 1113, 2008.

28. KARADEMIR Ç., KARADEMIR E., DORAN I., ALTIKAT A. Effect of different amounts of nitrogen and phosphorus on cotton yield and lint quality under Diyarbakir ecological conditions. Journal of Agriculture of Faculty, Gazi Osmanpasa University, 22 (1), 55, 2005 [In Turkish with English Abstract].

29. HARTZ T.K., HOCHMUTH G.J. Fertility Management of Drip-irrigated Vegetables. Vegetable Research and Information Center, UC. Davis, USA, 6, 2005.

30. YURTSEVER N. applied statistical methods. Research Institute of Soil-Fertilizer and Water Resources 56, 121, Ankara, Turkey, 2011 [In Turkish].

31. PAPASTYLIANOUA P.T., ARGYROKASTRITIS I.G. Effect of limited drip irrigation regime on yield, yield components, and fiber quality of cotton under Mediterranean conditions. Agricultural Water Management, 142, 127, 2014.

32. LIU C., ZHANG X., ZHANG Y. Determination of Daily evaporation and evapotranspiration of winter wheat and maize by large-scale weighing lysimeter and microlysimeter. Agricultural and Forest Meteorology, 111 (2), 109, 2002.

33. AZEVEDO P.V., BEZERRA J.R..C, SILVA V.R. Evapotranspiration and water-use efficiency of irrigated colored cotton cultivar in semiarid regions. Agricultural Sciences, 3 (5), 714, 2012.
34. SHRUTI M.Y., ALADAKATTI Y.R. Effect of drip irrigation and fertigation on yield, economics and water use efficiency of intra-hirsutum Bt cotton. Journal of Farm Science, 30 (2), 185, 2017.

35. SARWAR M.K.S., ASHRAF M.Y., REHMAN M., ZAFAR Y. Genetic variability in different biochemical traits and their relationship with yield and parameters of cotton cultivar grown under water stress conditions. Pakistan Journal of Botany, 44, 515, 2012.

36. YANG P., HU H., TIAN F., ZHANG Z., DAI C. Crop coefficient for cotton under plastic mulch and drip irrigation based on eddy covariance observation in an arid area of northwestern China. Agricultural Water Management, 171, 21, 2016.

37. EVETT S.R., HOWELL T.A, SCHNEIDER A. Energy and water balances for surface and subsurface drip irrigated corn. International Water and Irrigation Reviev, 20 (4), 18, 2000.

38. LUO Y., OUYANG Z., ZHAO Q., YU Q. Modelling maximal evapotranspiration and crop coefficient. Available online, http,//www.klter.or/EVENTS (accessed on 25 June 2019)

39. KETEN M. The Effects of different irrigation levels on different cotton genotypes and water-yield relationships. Kahramanmaraş Sütçü İmam University, Applied Sciences Institute, M Sc. Thesis, Dept Biosys Eng, Kahramanmaraş, Turkey, 48, 2016 [In Turkish with English abstract].

40. PHENE C.J., HUTMACHER R.B., DAVIS K.R. Subsurface drip irrigation, cotton does not need to be a high water user. Proceedings of Cotton Engineering Systems Conference, 489, 1992.

41. ÇETIN Ö., KÖKSAL E.S. Approaches on crop evapotranspiration for drip irrigation. Proceedings of $2^{\text {nd }}$ National Symposium on Irrigation and Agricultural Structures 24-25 May, Bornova/İzmir, Turkey 2012 [In Turkish with English abstract].

42. TIAN F., YANG P., HU H., DAI C. Partitioning of cotton field evapotranspiration under mulched drip irrigation based on a dual crop coefficient model. Water, 8, 72, 2016.

43. WANG Y., LI S., QIN S., GUO H., YANG D., LAM H.M. How can drip irrigation save water and reduce evapotranspiration compared to border irrigation in arid regions in northwest China. Agricultural Water Management, 239, 106256, 2020.

44. KUMAR M.D. Water saving and yield enhancing micro irrigation technologies in India. In, Viswanathan, M.D., Kumar, A., Narayanamoorth, M. (Eds.), Theory and Practice, Micro Irrigation Systems in India, India Studies in Business and Economics. 13, 2016.

45. ZONTA J.H., BRANDÃO Z.N., SOFIATTI V., BEZERRA J.R., MEDEIROS J.C. Irrigation and nitrogen effects on seed cotton yield, water productivity and yield response factor in semi-arid environment. Australian Journal of Crop Science, 10 (1), 118, 2016.

46. RAO S.S., TANWAR S.P.S., REGAR P.L. Effect of deficit irrigation, phosphorous inoculation and cycocel spray on root growth, seed cotton yield and water productivity of drip irrigated cotton in arid environment. Agricultural Water Management, 169, 14, 2016.

47. SAMPATHKUMAR T., RANGASWAMY M.V., PANDIAN B.J., MANICKASUNDARAM P., JEYAKUMAR P. Influence of deficit irrigation on growth, yield and yield parameters of cotton-maize cropping sequence. Agricultural Water Management, 130, 90, 2013. 
48. CHEVIRON B., VERVOORT R.W., ALBASHA R., DAIRON R., PRIOL C.L., MAILHOL J.C. A framework to use crop models for multi-objective constrained optimization of irrigation strategies. Environmental Modelling \& Software, 86, 145, 2016.
49. THORP K.R., HUNSAKER D.J., BRONSON K.F., ANDRADE-SANCHEZ P., BARNES E.M. Cotton irrigation scheduling using a crop growth model and FAO-56 methods, field and simulation studies. Transactions of ASABE 60 (6), 2023, 2017. 